\title{
Filmowe spotkania $z$ Innym jako forma dialogu międzykulturowego
}

Streszczenie: Przedmiotem rozważań zawartych w artykule są wybrane obszary kultury filmowej skupiające się na problematyce Innego. Refleksja nad rolą filmu w spotkaniu z Innym stanowi próbę znalezienia odpowiedzi na pytanie, jak i w jakim celu wybrane filmy dokumentalne i fabularne ukazują Innego. Twórcy filmowi coraz częściej poruszają tematykę dotyczącą wielokulturowości, odmienności etnicznych czy kryzysu migracyjnego. W obliczu narastających problemów dotyczących braku tolerancji, szacunku czy wrogości wobec Innego film może być pomocny w kształtowaniu postaw otwartości na inność, opartych na uniwersalnych wartościach, na szacunku do różnorodności kulturowej i etnicznej. Filmy stanowią medium umożliwiające spotkanie z drugą osobą (Innym), pozwalają na prezentację i wymianę rozmaitych wartości i perspektyw. Filmowcy nie proponują systemowych rozwiązań, ale wykorzystują kamerę jako jedno z narzędzi zmiany; przez ilustrację konkretnego problemu starają się budować poczucie sprawiedliwości i odpowiedzialności za Innego.

Słowa kluczowe: film, spotkanie, Inny, migranci, dialog międzykulturowy, edukacja międzykulturowa

\section{Wprowadzenie}

W obliczu narastających w różnych częściach świata problemów dotyczących braku tolerancji, szacunku czy wrogości wobec Innego kultura i jej teksty (w tym film) stają się pomocne w komunikacji między ludźmi różnych kultur, tworząc możliwość spotkania z drugim człowiekiem. Nie można współcześnie nie dostrzegać roli mediów, zarówno nowych, jak i tradycyjnych, w budowaniu relacji i interakcji międzykulturowych; jednym z nich, które wykorzystuje kategorię spotkania z Innym, jest kino. Refleksja nad figurą Innego skupiona wokół myśli Emmanuela Lévinasa i Józefa Tischnera jest próbą wskazania wybranych obszarów współczesnej kultury filmowej pomocnych w praktyce edukacyjnej. 
Kino światowe od dziesięcioleci podejmuje temat inności i Innego, który w zależności od epoki i jej polityczno-społecznych uwarunkowań jest rozmaicie interpretowany. Omówieniem tej problematyki w kinie europejskim zajął się Krzysztof Loska w książce Postkolonialna Europa. Etnoobrazy współczesnego kina (Loska, 2011). Twórcą, którego dorobek obfituje w obrazy analizujące kategorię Innego, jest australijski reżyser Peter Weir: „Bohaterem filmów Weira jest zazwyczaj outsider, człowiek z zewnątrz, który próbuje poznać i zrozumieć inną kulturę lub też inną społeczność" (Haltof, 2005, s. 230). Również kino popularne coraz częściej konfrontuje widza z ideą wielokulturowości oraz skłania do namysłu nad wzajemną akceptacją i tolerancją kulturowego zróżnicowania. W najnowszych filmach ukazywanie mniejszości etnicznych i rasowych łączy się z refleksją nad ruchami migracyjnymi oraz problemami wielokulturowych społeczeństw. Niemożliwe jest dokonanie przeglądu dorobku światowego kina podejmującego tematykę Innego w jednym artykule, zatem celem moich rozważań jest próba znalezienia odpowiedzi na pytanie, jak i w jakim celu wybrane filmy dokumentalne i fabularne ukazują Innego, oraz wskazanie filmowych obrazów i działań w obrębie kultury filmowej, które mogą znaleźć zastosowanie w edukacji międzykulturowej.

\section{Spotkanie i odpowiedzialność za Innego}

Kategoria spotkania jest przedmiotem filozofii dialogu nazywanej też filozofią spotkania lub filozofią innego, nie są to jednak do końca określenia równoważne. Dialog jest możliwy, gdy następuje spotkanie, a ono jest warunkiem zaistnienia dialogu (Kłoczkowski, 2005, s. 23), który stanowi najbardziej efektywną formę otwartej komunikacji między ludźmi oraz pozwala na prezentację i wymianę rozmaitych perspektyw w spotkaniu z drugą osobą (Innym). Ideę Innego jako bytu jedynego i niepowtarzalnego można odnaleźć w pismach filozofów dialogu takich jak Emmanuel Lévinas, Martin Buber, Gabriel Marcel czy Józef Tischner.

Spotkanie z Innym w rozumieniu Lévinasa (1998) jest wydarzeniem ocalającym oraz wywyższającym człowieka, które wymaga nie tylko stawania z nim twarzą w twarz, ale i wzięcia za niego odpowiedzialności. „Twarz, którą inny człowiek zwraca w moją stronę, nie rozpuszcza się w przedstawieniu twarzy. Słyszeć nędzę, która woła o sprawiedliwość, nie znaczy przedstawiać sobie jakiś obraz, lecz stawać się odpowiedzialnym, być jednocześnie czymś więcej i czymś mniej niż byt uobecniający się w twarzy" (Lévinas, 1998, ss. 255-256). Pojęcie odpowiedzialności stanowi ważny wątek rozwa- 
żań filozoficznych Lévinasa (2000), które filozof ujmuje w perspektywie dobra rozumianego jako istota istnienia. Odpowiedzialność jest nierozerwalnie związana z podmiotem, odpowiedzialność podmiotu traktowana jest jako odpowiedź Innemu: „Odpowiedzialność za drugiego człowieka - nieograniczona odpowiedzialność, która nie mieści się w rachunku tego, co wolne i niewolne - wymaga podmiotowości jako niezastępowalnego zakładnika; podmiotowości, która zostaje wydobyta spod ja w bierności prześladowania, która jest zepchnięta i wygnana poza istotę ku Sobie. Sobość poza istotą śmiertelna bierność" (Lévinas, 2000, s. 211).

Dla Józefa Tischnera spotkanie jest zawsze wydarzeniem: „Doświadczamy innego spotykając go. Spotkać to coś więcej niż mieć świadomość, że inny jest obecny obok mnie lub przy mnie. (...) Spotkanie jest wydarzeniem. Spotkanie pociąga za sobą istotną zmianę w przestrzeni obcowań" (Tischner 1999, s. 27). O spotkaniu z drugim człowiekiem Tischner pisze: „Spotykając drugiego (innego), spotykam go w horyzoncie, który w ogóle umożliwia spotkanie i zarazem jest jego dziełem. Spotkany inny i ja wraz z nim znajdujemy się w przestrzeni, w której coś jest lepsze, a coś gorsze, dobre lub złe" (Tischner, 1999, s. 63).

Od zarania spotkanie z innym człowiekiem było powszechnym i podstawowym doświadczeniem międzyludzkim. Jak zauważa Ryszard Kapuściński (2004): „trzy możliwości stały zawsze przed człowiekiem, ilekroć spotkał się z Innym; mógł wybrać wojnę, mógł odgrodzić się murem, mógł nawiązać dialog. Na przestrzeni historii człowiek cały czas waha się pomiędzy tymi opcjami, w zależności od czasu i kultury wybiera to jedną, to drugą" (Kapuściński, 2004, s. 10). Podczas wykładu wygłoszonego z okazji przyznania tytułu doktora honoris causa Uniwersytetu Jagiellońskiego w 2004 roku Kapuściński (2004) przekonywał, że spotkanie z Innym stanowi wyzwanie XXI wieku.

\section{Festiwale filmowe jako przestrzeń spotkania z Innym}

Film, tak fabularny, jak i dokumentalny, jako powszechny i łatwo dostępny tekst kultury, może być społecznie użyteczny. Dzisiaj głównym forum dyskusji społecznej i politycznej prowadzonej za pośrednictwem filmowego medium są festiwale. $\mathrm{Na}$ festiwalach rzadko pokazywane są filmowe przeboje, zamiast nich widzowie mają okazję oglądać filmy trudne, pobudzające do dyskusji, często ukazujące miejsca, w których powstały, z ich problemami i konfliktami społeczno-politycznymi. Festiwale konstruują swoisty dyna- 
miczny system, gdzie kino jako istotna sfera kultury nieustannie dąży do redefiniowania swojego znaczenia i miejsca w najbliższym, lokalnym środowisku, w przestrzeni audiowizualnej oraz w kontekście socjoekonomicznym i politycznym (Wong, 2011, ss. 1-2). Na festiwalach można zobaczyć filmy, które nie zawsze trafiają do powszechnej dystrybucji, rozpowszechniane są zwykle w sieci kin studyjnych lub w formule objazdowej.

Przedsięwzięciem wpisującym się w dialog międzykulturowy oraz w ideę spotkania z Innym jest Międzynarodowy Festiwal Filmowy WATCH DOCS. Prawa Człowieka w Filmie. Na festiwalu odbywającym się cyklicznie od 2001 roku pokazywanych jest corocznie kilkadziesiąt filmów. Projekcje odbywają się w Warszawie oraz w ramach festiwalu objazdowego w czterdziestu innych polskich miastach; festiwal ma także wersję on-line, co poszerza jego grono widzów do ponad stu tysięcy rocznie. Podczas każdej edycji organizatorzy przygotowują kilkadziesiąt premierowych pokazów filmowych, wiele spotkań ze światowej sławy dokumentalistami, spotkania i dyskusje panelowe z udziałem ekspertów, obrońców praw człowieka, publicystów i polityków. Festiwal stanowi wspólne przedsięwzięcie Helsińskiej Fundacji Praw Człowieka, Centrum Sztuki Współczesnej Zamek Ujazdowski w Warszawie i Społecznego Instytutu Filmowego, które wspierane jest przez najważniejszych polskich i europejskich mecenasów sztuki filmowej i kultury praw człowieka (m.in. Instytut Społeczeństwa Otwartego (Open Society Institute, New York), Komisję Europejską, Polski Instytut Sztuki Filmowej, Fundusz Inicjatyw Obywatelskich, Mechanizm Finansowy EOG i Norweski Mechanizm Finansowy, Advocate Europe, Nordic Council of Ministers, Biuro Kultury m.st. Warszawy, Instytut Francuski, British Council ${ }^{1}$ ).

O kilka lat młodszy Millennium Docs Against Gravity Film Festival odbywa się równolegle w pięciu polskich miastach: Warszawie, Gdyni, Wrocławiu, Bydgoszczy i Lublinie. Festiwal Filmowy Millennium Docs Against Gravity jest współzałożycielem i członkiem Doc Alliance, zrzeszającym siedem kluczowych europejskich festiwali filmów dokumentalnych: CPH:DOX Kopenhaga, DOK Lipsk, MFFD Jihlava, FID Marseille, Visions du Réel, Nyon, Doclisboa i Festiwal Filmowy Millennium Docs Against Gravity². Jego program oparto na pełnometrażowych filmach dokumentalnych prezentowanych i nagradzanych na wielu innych światowych festiwalach filmowych, m.in. Sundance Film Festival w Park City w USA (istniejący od 1978 roku) gdzie

1 https://watchdocs.pl/2018/a/pl/artykul/7/o_nas (21.01.2019).

2 https://mdag.pl/16/pl/warszawa/page/o-festiwalu (12.02. 2019). 
pokazywane są głównie filmy niezależne, podejmujące refleksję nad współczesnym światem i jego problemami.

Kilka ważnych społecznie filmów ostatnich lat miało swą premierę właśnie na festiwalu w Sundance, jak np. Ostatni w Aleppo (Last men in Aleppo, reż. Firas Fayyad, 2017), syryjsko-duński film, laureat tego festiwalu z 2017 roku. Poruszający obraz tragedii Syryjczyków, którego głównym bohaterem jest Khaled ratownik - ochotnik Białych Hełmów, organizacji zrzeszającej cywilów, ratujących ofiary bombardowań spod gruzów w Aleppo. Film jest relacją z wojennego koszmaru, pokazującą niezawinioną śmierć syryjskich cywili i dzieci oraz poświęcenie w ratowaniu tych, którzy nie mogą albo nie chcą opuścić swego kraju. Jest wołaniem o pomoc oraz argumentem za jej bezwarunkową koniecznością w dyskusji na temat przyjmowania uchodźców przez państwa europejskie. Jako dramatyczne spotkanie z Innym przypomina o odpowiedzialności za losy ludzi uciekających przed wojną.

Również Stodki koniec dnia (Dolce fine giornata, 2019) fabularny film Jacka Borcucha, który miał swą premierę na Sundance Film Festival, można rozpatrywać w perspektywie odpowiedzialności za Innego. Akcja filmu opowiadającego o hipokryzji Europejczyków umiejscowiona została w etruskiej Volterze w Toskanii. Jego bohaterka, polska poetka, noblistka, podczas publicznego wystąpienia zabiera głos w sprawie uchodźców i kryzysu migracyjnego. Jej bezkompromisowa postawa spotyka się z ostrą krytyką i nieprzyjemnymi konsekwencjami ze strony środowiska. W filmie poruszona została tematyka uchodźców oraz wrogości wobec nich i niechęci Europejczyków do dialogu i zaangażowania się w działania zgodnie z etyką solidarności (Tischner, 2018), opierającej się na odpowiedzialności za drugiego człowieka (Lévinas, 2000) oraz szczególnej formie więzi międzyludzkiej wymagającej udzielenia pomocy i opieki tym, którzy jej potrzebują.

Jury jednego z najstarszych festiwali filmowych w Cannes coraz częściej wyróżnia filmy nacechowane dużym ładunkiem społecznej wrażliwości i ukierunkowane na budowanie poczucia odpowiedzialności za Innego. Uhonorowany Nagrodą Jury film Nadine Labaki Kafarnaum (Capharnaüm, 2018) w poruszający sposób opowiada o dwunastoletnim uchodźcy z Syrii; ukazuje współczesny Liban z jego palącymi problemami, czyli nędzę, konsekwencje wojennej przemocy, pedofilię, handel dziećmi, przedmiotowe traktowanie kobiet, emigrację zarobkową. Reżyserka jest przekonana, że kino ma wpływ na ludzi i ich stosunek do świata, może prowokować do działań skupiających się na pomocy konkretnym jednostkom. Jako przykład podaje losy chłopca odtwarzającego główną rolę w Kafarnaum. Zain Al Rafeea - nastoletni 
uchodźca z Syrii otrzymał wraz z rodziną azyl polityczny w Norwegii, przed udziałem w filmie nie potrafił czytać i pisać, teraz robi to w dwóch językach. Labaki deklaruje, że za pośrednictwem narzędzi, jakimi dysponuje, będzie dokładała starań, aby jej filmy nie tylko budziły empatię, poruszały, ale przede wszystkim przekładały się na konkretne zachowania i działania (Labaki, 2019). Emmanuel Lévinas (1998) w rozważaniach na temat twarzy człowieka, szczególne znaczenie przypisuje spotkaniom twarzą w twarz. Takim właśnie spotkaniem jest ostatnie ujęcie w filmie Kafarnaum, kiedy cały ekran wypełnia zbliżenie twarzy dziecka, które wzywa i zobowiązuje do odpowiedzialności za drugiego człowieka.

Inny film dostępny w festiwalowym obiegu pt. Muzyka obcych (The Music of Strangers, reż. Morgan Neville, 2015) jest zapisem projektu o nazwie Silk Road Ensamble. Projekt zgromadził muzyków mieszkających w krajach dawnego Szlaku Jedwabnego, łączącego Państwo Środka z Europą. W skład zespołu weszli artyści z hiszpańskiej Galicji, Syrii, Iranu, Chin oraz amerykański wiolonczelista pochodzenia chińskiego Yo-Yo Ma. Muzyczna podróż przez kolejne kraje i spotkania z ich mieszkańcami ukazuje troskę o dziedzictwo kulturowe i potrzebę wspólnego dążenia do zachowania i kultywowania tradycji. Muzyka obcych jest obrazem wpisującym się w międzykulturowy dialog, ilustruje spotkanie z Innym, będące źródłem wiedzy o wartościach i normach akceptowanych przez przedstawicieli innych kultur, ale także wiedzy o własnej tradycji kulturowej. Zarówno film, jak i muzyka, jako ważne przekazy kulturowe, mogą pełnić rolę „interlokutora” w sytuacji spotkania i dialogu oraz uświadomienia przyczyn różnorodności czy rozbieżności kulturowych. Umiejętność dostrzegania różnic w połączeniu z akceptacją odmienności może przysłużyć się do wytworzenia bardziej refleksyjnego stosunku nie tylko do innej, ale i własnej kultury, ale przede wszystkim do wzajemnego uznania i szacunku.

\section{Narracje Migrantów}

Mimo że filmy bezpośrednio nie przyczyniają się do zmian społecznych, to mają potencjał ich inicjowania przez moc kształtowania ludzkiej wrażliwości, opinii, poglądów czy postaw. Stanowią okazję do spotkania z drugim człowiekiem, jego doświadczeniami, problemami, pragnieniami, oczekiwaniami. Zwłaszcza filmy dokumentalne, których oddziaływanie na widzów, ze względu na oczekiwania odbiorcze i przekonanie o autentyczności zarejestrowanych obrazów, jest silniejsze niż filmów fabularnych. Bohaterowie tych 
filmów budzą empatię, a ich losy poruszają. Film dokumentalny jest rodzajem filmowym najczęściej definiowanym przez teoretyków i dokumentalistów. Mirosław Przylipiak, autor rozprawy na temat poetyki kina dokumentalnego, przyczyn tego stanu rzeczy szuka w niejasnym statusie dokumentu filmowego, jego wyznaczników i kryteriów, które często formułowane są intuicyjnie. Odbiorcy raczej nie mają problemu z odróżnieniem filmów dokumentalnych od fabularnych, jednakże trudność sprawia im opisanie ich specyfiki. Przylipiak (2004) po dokonaniu przeglądu istniejących definicji, jego zdaniem mało satysfakcjonujących, zaproponował ich uzupełnienie o tezę mówiącą, że struktura filmu dokumentalnego powinna naśladować właściwe dla człowieka sposoby porządkowania rzeczywistości.

Z inicjatywy Fundacji na rzecz Różnorodności w latach 2010-2014 powstała seria filmowa Narracje Migrantów, która składa się z dziewięciu krótkich, kilkuminutowych filmów dokumentalnych udostępnianych na płytach DVD oraz kanale YouTube (filmy dostępne są w kilku wersjach językowych). Narratorkami i narratorami są osoby, które z różnych powodów opuściły swój kraj i zamieszkały w Polsce. Słowo „migrant” w tytule, jak piszą autorzy projektu, „nie odnosi się jednak do statusu prawnego, a raczej do sposobu bycia, mentalności, doświadczenia życiowego bohaterów i bohaterek filmów. Część z nich jest w Polsce tylko przejazdem, inni decydują się na dłuższy pobyt albo chcą się tutaj osiedlić, niektórzy się tu urodzili. Ważne jest to, że mają coś szczególnego do powiedzenia o tym, jak czują się w Polsce i w jaki sposób ją postrzegająa ${ }^{3}$.

Bohaterki i bohaterowie filmów pochodzą między innymi z Czeczenii ( $F a-$ tima, 2012, Aslan i jego uczniowie, 2010; Moje miasto Łomża, 2012, reż. Rafał Skalski); Wietnamu (Po polsku mam na imię Hania, 2014, reż. R. Skalski), Egiptu (To co najlepsze z dwóch światów. Syn Mohameda, 2010, reż. Maciej Jaszczak), Nigerii (Dlaczego jestem czekoladowy?, 2010, reż. R. Skalski), Ukrainy (Wymiana, 2010, reż. M. Jaszczak). Z perspektywy własnych doświadczeń opowiadają nie tylko o sobie, ale i o Polsce i Polakach. Dzielą się refleksjami dotyczącymi trudności z asymilacją, problemów z tożsamością kulturową i etniczną, mówią o trudnych relacjach ze społecznością lokalną. Te krótkie filmy dają możliwość spotkania z Innym, zwracają uwagę na problem migracji oraz różnorodności społecznej w Polsce, są punktem wyjścia do dyskusji na temat problemu tolerancji, dyskryminacji, uchodźctwa, polityki integracyjnej wobec migrantów i uchodźców. Poruszają też tematykę równe-

3 http://ffrs.org.pl/aktualne-dzialania/nm/ (13.05.2019). 
go dostępu do edukacji dzieci z doświadczeniem migracyjnym oraz dotykają problemu komunikacji międzykulturowej.

Fundacja udostępnia filmy w celach edukacyjnych, można je wykorzystać jako narzędzia w edukacji międzykulturowej do zajęć z dziećmi i młodzieżą oraz osobami dorosłymi. Na portalu internetowym fundacji są dostępne przykłady zastosowania filmów w praktyce edukacyjnej, ponadto istnieje możliwość zaproszenia do współpracy „edukatorów i edukatorek FRS, którzy i które, mogą poprowadzić warsztat, szkolenie lub dyskusję w oparciu o film"4.

\section{Spotkania, które zmieniają}

Filmowe spotkania z innymi ludźmi, kulturami, religiami, ideami mogą być wydarzeniami w rozumieniu Tischnera (1999), mimo że pozbawione są bezpośredniości. Szczególnie dla osób, które takich bezpośrednich spotkań nie mają okazji lub możliwości doświadczać. Film jako powszechnie dostępne medium nadaje się do aranżowania spotkań mających moc znaczącego, choć pośredniego, wydarzenia.

Wrocławskie Stowarzyszenie Nowe Horyzonty od kilkunastu lat zajmujące się edukacją filmową (Nowe Horyzonty Edukacji Filmowej), w roku szkolnym 2018/2019 w ramach jednego z kilku cykli edukacyjno-filmowych zaproponowało temat Między kulturami. Cykl filmów wraz z prelekcjami skierowany został do uczniów ostatnich klas szkoły podstawowej i wygaszanych gimnazjów. Autorzy tej inicjatywy tak o niej piszą: „Cykl Między kulturami to podróż przez świat różnorodnych kultur, religii, systemów politycznych. Pozwala on na zgłębianie wiedzy o bliskich dzięki globalizacji, lecz odległych kulturowo zakątkach świata. Nowa wiedza przeplata się $\mathrm{z}$ uniwersalnymi wartościami, co pozwala uczniom na sprawne odnalezienie się w nowych krajobrazach przy jednoczesnym odczuwaniu różnicy. Dzięki temu proponowane filmy stają się także doskonałymi kontekstami dla lektur czytanych w szkole. Pozwalają na dostrzeżenie wspomnianych podobieństw i różnic oraz uwspółcześnieniu omawianych zagadnień. Poza wiedzą dotyczącą asymilacji, izolacji, tożsamości etnicznej czy narodowej w widzach kształtowana będzie postawa tolerancji i empatii" .

Program cyklu obejmuje wybrane filmy kinematografii światowej ilustrujące konkretne problemy, z którymi borykają się młodzi bohaterowie. Wśród

4 http://ffrs.org.pl/aktualne-dzialania/nm/ (13.05. 2019).

5 https://nhef.pl/program/cykle/miedzy-kulturami (21.03. 2019). 
proponowanych do zainicjowania dyskusji na tematy związane z wielokulturowością czy odmiennością etniczną są obrazy zrealizowane głównie w ostatniej dekadzie w Europie, Australii, Azji i na Bliskim Wschodzie, często przez filmowców posiadających imigracyjne doświadczenie.

Jeden z filmów cyklu Goodbye Berlin (Tschick, 2016) w reżyserii Fatiha Atkina (potomka tureckich emigrantów urodzonego w Hamburgu) opowiada o przyjaźni dwóch nastolatków, zaniedbanego emocjonalnie przez rodziców Niemca Maika i Tschicka, rosyjskiego imigranta o azjatyckiej urodzie. Film jest adaptacją popularnej powieści dla młodzieży pt. Tschick autorstwa Wolfganga Herrndorfa. Tschick różni się od innych bohaterów filmów Fatiha Atkina tym, że nie czuje się w żaden sposób wykorzeniony i nie ma jakichkolwiek kompleksów związanych z przynależnością etniczną i religijną (żartuje, że jest cygańskim Żydem albo żydowskim Cyganem). W tym awanturniczym duecie podróżującym starą ładą na Wołoszczyznę to on jest pełnym energii i radości życia liderem. Reżyser zwraca uwagę, że młode pokolenie buduje własną tożsamość już nie w oparciu o przynależność etniczną i doświadczenia z przeszłości rodziców czy dziadków, ale z wykorzystaniem uniwersalnego bagażu kulturowego czerpanego z mediów, filmów, seriali oraz gier komputerowych.

Pozostałe filmy wybrane przez autorów projektu: Fighter - kochaj $i$ walcz (reż. N. Arthy, Dania 2008). Dziewczynka w Trampkach (Wadjada), reż. H. Al-Mansour, 2012, Holandia, Niemcy USA, Jordania, Zjednoczone Emiraty Arabskie, Arabia Saudyjska), Bez granic (Bedone marz, reż. A. Asgari, Iran, 2014) Cygan (Cigan, reż, Martin Šulík, Czechy, Słowacja, 2011) Rakieta (The Rocket), reż. K. Mordaunt, Australia, Tajlandia, Laos, 2013; Slumdog milioner $z$ ulicy (Slumdog. Millionaire, reż. D. Boyle, Wielka Brytania, 2011) obracają się w kręgu tematów dotykających problemów z tożsamością kulturową oraz buntu młodych bohaterów wobec stereotypów i uprzedzeń, jakie rodzi przynależność etniczna, religijna i kulturowa.

Celem programu edukacyjno-filmowego Między kulturami jest zwrócenie uwagi na różne tożsamości społeczno-kulturowe (regionalną, narodową, etniczną, państwową, obywatelską, europejską), z których zbudowane są wizerunki filmowych bohaterów. Ponadto prezentowane w cyklu obrazy mogą służyć wychowaniu przeciw ksenofobii, rasizmowi, szowinizmowi i antysemityzmowi oraz uczyć przeciwstawiania się takim zjawiskom ${ }^{6}$.

W roku szkolnym 2019/2020 uczniowie szkół ponadpodstawowych wraz z nauczycielami będą natomiast mogli wziąć udział w cyklu Wielokulturowość

6 https://nhef.pl/program/cykle/miedzy-kulturami (21.03. 2019). 
w filmie, którego program będzie zawierał filmy (między innymi omawiany wcześniej Kafarnaum) skłaniające do dyskusji „o swojskości i obcości w kulturze, o budowaniu wspólnoty i akceptowaniu odmienności etnicznej czy kulturowej, o asymilacji i poszanowaniu prawa do poszukiwania miejsca do godnego życia"7.

Spotkania z Innym za pośrednictwem filmu konstruują horyzont poznawczy, etyczny i estetyczny uczniów. Kino pokazuje życie i związane z nim problemy w innych kulturach, jednocześnie skupiając się na tym, co wspólne, na pokoleniowym doświadczeniu i humanistycznych wartościach wyznawanych niezależnie od przynależności narodowej i kulturowej; skłania do refleksji i pomaga kształtować opinie na temat wielokulturowego, pluralistycznego, otwartego na odmienności świata. Zainicjowane za sprawą filmów spotkanie z Innym może prowadzić do wyzbycia się bierności, ukształtowania postawy otwartości i wzięcia odpowiedzialności za Innego oraz do refleksji nad rolą człowieka we współczesnym świecie.

\section{Zakończenie}

W artykule zwrócono uwagę na wybrane obszary kultury filmowej (festiwale, projekty, programy i filmy), skupiające się na problematyce Innego. Rozważania w oparciu o refleksję wykorzystującą myśli Emmanuela Lévinasa i Józefa Tischnera stanowią próbę wskazania filmów fabularnych i dokumentalnych oraz inicjatyw i projektów filmowych, które mogą zostać wykorzystane w edukacji międzykulturowej. Celem namysłu nad wybranymi filmami była próba znalezienia odpowiedzi na pytanie, jak i w jakim celu wybrane filmy dokumentalne i fabularne ukazują Innego. W omawianych filmach twórcy wykorzystują kamerę jako jedno z narzędzi zmiany i próbują upominać się o najsłabszych. Filmowe obrazy, traktowane jako przestrzeń spotkania z Innym, nie mają mocy zmieniania świata, nie wskazują gotowych rozwiązań, ale przez umiejętną ilustrację konkretnego problemu poruszają, wywołują empatię, przeciwdziałają obojętności oraz spełniają istotną rolę w edukacji międzykulturowej, bo jak zauważa Katarzyna Olbrycht (2007), dialogu z innymi kulturami trzeba się nauczyć, między innymi przez wychowanie do szacunku do kultur, własnej oraz innej. Takie wychowanie rozpatrywane z perspektywy aksjologicznej „obejmuje działania zmierzające do poszukiwania i odkrywania w każdej kulturze tych prób, wysiłków, dokonań, które świadczą o dążeniu do

\footnotetext{
7 https://nhef.pl/program/cykle/wielokulturowosc-w-filmie (13.05.2019).
} 
podnoszenia człowieczeństwa, nadawaniu głębszego sensu życiu ludzkiemu (...), poznanie, zrozumienie i przyjmowanie szacunku wobec najistotniejszych w danej kulturze wartości ludzkich" (Olbrycht, 2007, s. 31).

Kino poruszające aktualne i ważne społecznie tematy ma szansę odegrać ważną rolę w spotkaniu z Innym, w dialogu pomiędzy kulturami, jak również w edukacji międzykulturowej. Przez prezentację problemu odmienności etnicznych i kulturowych czy kryzysu migracyjnego wspiera kształtowanie postaw otwartości na świat oraz szacunku do innych kultur, jak również wzywa do wzięcia odpowiedzialności za Innego. Filmy mogą pełnić rolę „interlokutora” w sytuacji dialogu, uświadamiać przyczyny różnorodności czy rozbieżności kulturowych, wspomagać budowanie otwartego i zróżnicowanego społeczeństwa.

\section{Bibliografia}

Haltof, M. 2005. Kino australijskie. Gdańsk: Wydawnictwo słowo/obraz terytoria.

Kapuściński, R. 2004. Spotkanie z Innym jako wyzwanie XXI wieku. Kraków: Universitas.

Kłoczowski, J.A. 2005. Filozofia dialogu. Poznań: W drodze.

Labaki, N. 2019. Minimum szczęścia. Zwierciadło. 3 (2069), ss. 38-42.

Lévinas, E. 1998. Całość i nieskończoność. Esej o zewnętrzności. Warszawa: Wydawnictwo Naukowe PWN.

Lévinas, E. 2000. Inaczej niż być lub ponad istota. Warszawa: Fundacja Aletheia.

Loska, K . 2011. Postkolonialna Europa. Etnoobrazy wspótczesnego kina. Kraków: Universitas.

Między kulturami. https://nhef.pl/program/cykle/miedzy-kulturami (21.03. 2019).

Międzynarodowy Festiwal Filmowy WATCH DOCS. Prawa Człowieka w Filmie. https://watchdocs.pl/2018/a/pl/artykul/7/o_nas(21.01.2019).

Millennium Docs Against Gravity Film Festival. https://mdag.pl/16/pl/warszawa/page/o-festiwalu (12.02. 2019).

Narracje Migrantów. http://ffrs.org.pl/aktualne-dzialania/nm/ (13.05.2019). Olbrycht, K. 2007. Aksjologiczny sens upowszechniania kultury i edukacji kulturalnej. W: Olbrycht, K., Konieczna, E. i Skutnik, J. red. Upowszechnianie kultury - wyzwaniem dla edukacji kulturalnej. Toruń: Wydawnictwo Adam Marszałek, ss. 27-37. 
Przylipiak, M. 2004. Poetyka kina dokumentalnego. Gdańsk: Wydawnictwo słowo/obraz terytoria.

Tischner, J. 1999. Filozofia dramatu. Kraków: Znak.

Tischner, J. 2018. Etyka solidarności i Homo Sovieticus. Kraków: Znak.

Wielokulturowość w filmie. https://nhef.pl/program/cykle/wielokulturowosc-w-filmie (13.05.2019).

Wong, C.H. 2011. Film festivals: culture, people and power on the global screen. Piscataway: Rutgers University Press.

\title{
Film encounters with the Other as a form of intercultural dialogue
}

\begin{abstract}
The subject of the discussion contained in the article are selected spaces of film culture focusing on the issues of the Other. This objective of this article is also to present the role of the film in encounter with the Other and an attempt to find an answer to the question of how and for what purpose selected documentary and feature films speaking about the Other? Filmmakers are more and more concerned with the subject of multiculturalism, ethnic differences or the migratory crisis. In the face of growing problems concerning intolerance, respect or hostility towards Another, the film may be helpful in shaping attitudes of openness to otherness, based on universal values and on respect for cultural and ethnic diversity. The cinema allows encounter with the Other. Films present different values and perspectives and allow for their exchange. Filmmakers do not propose system solutions, but they use the movie camera as one of the tools of change. They are illustrating a specific problem and try to build a sense of justice and responsibility for the Other.
\end{abstract}

Keywords: film, encounter, Other, migrants 